\title{
Akt Inhibitor LY2780301
}

National Cancer Institute

\section{Source}

National Cancer Institute. Akt Inhibitor LY2780301. NCI Thesaurus. Code C95737.

An orally bioavailable inhibitor of the serine/threonine protein kinase Akt (protein kinase B) with potential antineoplastic activity. Akt inhibitor LY2780301 binds to and inhibits the activity of Akt, which may result in inhibition of the PI3K/Akt signaling pathway, thereby leading to inhibition of cell proliferation and the induction of apoptosis in tumor cells. Activation of the PI3K/Akt signaling pathway is frequently associated with tumorigenesis and dysregulated PI3K/Akt signaling may contribute to tumor resistance to a variety of antineoplastic agents. 